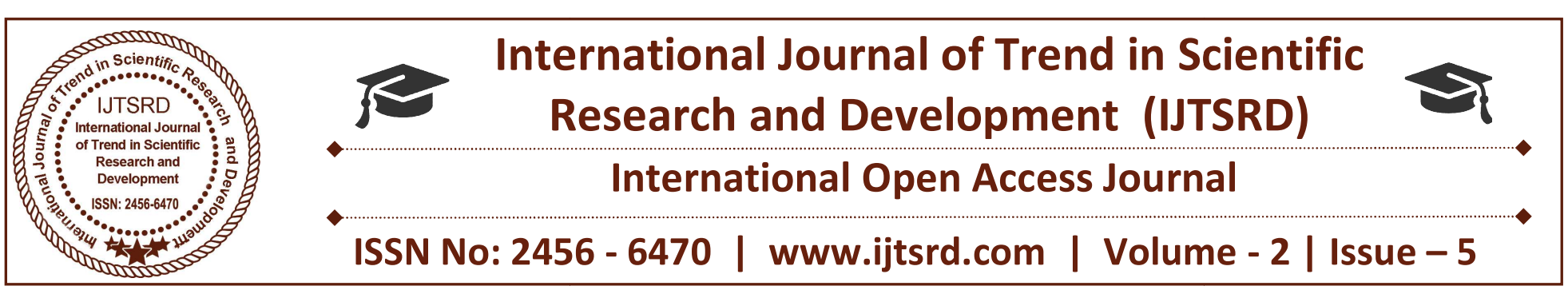

\title{
Statistical Analysis of Priority Sector Credit By Commercial Banks in India
}

\author{
Dr. O. Hari Babu \\ Associate Professor \\ SPIRTS MBA \& MCA College, \\ Kadapa, Andhra Pradesh, India
}

\author{
A. Srinivasulu \\ Research Scholor \\ Department of Statistics, S. V. University, \\ Tirupati, Andhra Pradesh, India
}

\section{Dr. R. V. S. S Nagabhushana Rao \\ Academic Consultant \\ Department of Statistics, Vikrama Simhapuri University \\ Nellore, Andhra Pradesh, India}

\begin{abstract}
Statistical Methods for Social Research using SPSS takes a more applied approach to conventional statistics by focusing on more analytical approach. Instead of being purely theory-oriented, emphasis will be more on the practical application of a variety of statistical techniques to supplied datasets. Working with datasets, it will cover widely-used statistical methods including descriptive statistics, data visualization, statistical inference, categorical data, correlation and regression, analysis of variance and multivariate analysis.
\end{abstract}

In the present study an attempt is made to analysis of commercial Banks credit towards Priority Sector credit which is most prominent topic in economic development and eliminating disparities. The key focus is on calculation and application of Compound growth rates and t-test. Compound growth rated are calculated to know the extent of growth factor in commercial banks' lending and t- test values are calculated to test the validity of growth rates. Thus, Statistical calculations part and parcel of every research for analyzing data, interpreting data and implementing policy decision. The present study is an endeavor in this direction.

Keywords: SPSS, Statistical Methods, t-test, commercial Banks, Compound growth

\section{INTRODUCTION}

The priority sector lending is mainly intended to ensure that assistance from banks to those sectors which have not received adequate support. The attainment of socio economic priorities like growth of agriculture, promotion of small entrepreneurs, development of backward areas etc. is the major

responsibility of government. Since 1970, Reserve Bank of India (RBI) and Government of India have stipulated guidelines for lending to priority sector lending by banks/ financial institutions. The same was revised during 2007 and overall priority sector lending target was fixed at 40 per cent for domestic banks and 32 per cent for foreign banks. The agricultural advances should be 18 per cent and weaker sections advances should be 10 per cent of total advances.

However, the banks are not able reach the prescribed target of lending to priority sector due to over dues mounting and non-performing assets (NPAs). Agricultural sector is the most important sector in India. The demand for agriculture arises due to increase in demand for agriculture produce, high yielding varieties, modernization, green revolution etc.

Moreover the demand for and supply of credit varies from region to region due to irrigation, nature and fertility of land climate etc. With this back drop the present study is an attempt to present the various lacunae of priority sector lending faced by commercial banks. 
2. COMMERCIAL BANKS ADVANCES TO PRIORITY SECTOR INCLUDING AGRICULTURE

Agricultural advances by commercial banks are direct and indirect. Development envisages transformation traditional subsistence farming into modernized activity. In view of this, commercial banks progressively entered into financing agriculture directly, which can be considered as a novel feature. Commercial banks have provided direct finance to farmers in the form of short-term crop loans for agricultural production and medium and long-term loan for increasing productivity of the land.

Short-term crop loans are usually given to farmers for periods ranging from six to twelve months and are mainly used for meeting seasonal requirements like seeds, manures, fertilizers and insecticides. Such advances are expected to be repaid at the time of the harvest.

The period of medium-term credit generally varies from one year to five years and is given for purposes such as purchase of tractors, power tillers, pump sets and bullocks. These loans are to be repaid by halfyears or annual instalment which usually coincides with the period of harvesting crop.

Long- term credit is generally for periods larger than five years against mortgage of immovable property.

Apart from supplying direct finance to farmers, commercial banks also provide finance to farmers indirectly through agencies and individuals, farmers' development agency. The commercial banks advances to agriculture (direct and indirect) and priority sector were shown in Table 1.

Table 1: Commercial Banks Advances to Priority Sector including Agriculture during 2008-17.

\begin{tabular}{|c|c|c|c|c|c|}
\hline \multirow{2}{*}{ Year } & \multicolumn{3}{|c|}{ Agricultural advances } & \multirow{2}{*}{$\begin{array}{c}\text { Priority sector } \\
\text { advances }\end{array}$} & \multirow{2}{*}{ Total advance } \\
\hline & Direct & Indirect & Total & & \\
\hline 2008 & $\begin{array}{l}5148.4 \\
(10.6)\end{array}$ & $\begin{array}{c}1901.7 \\
\text { of }(3.9) \text { end }\end{array}$ & in $\begin{array}{l}7050.1 \\
(14.5)\end{array}$ & $\begin{array}{c}25098.9 \\
(52)\end{array}$ & $\begin{array}{c}8908.66 \\
(100)\end{array}$ \\
\hline 2009 & $\begin{array}{c}6217.0 \\
(7.2)\end{array}$ & $\begin{array}{c}2226.5 \\
(2.6)\end{array}$ & $\begin{array}{l}8443.5 \\
(9.8)\end{array}$ & $\begin{array}{c}31133.6 \\
(36)\end{array}$ & $\begin{array}{c}11578.07 \\
(100)\end{array}$ \\
\hline 2010 & $\begin{array}{l}8303.8 \\
(7.4)\end{array}$ & $\begin{array}{l}2687.9 \mathrm{ve} \\
(2.4)\end{array}$ & $\begin{array}{c}10991.7 \\
(9.8)\end{array}$ & $\begin{array}{c}40077.5 \\
(35.6)\end{array}$ & $\begin{array}{c}15174.97 \\
(100)\end{array}$ \\
\hline 2011 & $\begin{array}{l}11212.6 \\
(7.4)\end{array}$ & $\begin{array}{c}4309.3 \\
(2.9)\end{array}$ & $\begin{array}{c}15521.7 \\
456 \\
(10.3)\end{array}$ & $\begin{array}{c}54677.3 \\
(36.2) \\
\end{array}$ & $\begin{array}{c}19470.96 \\
(100)\end{array}$ \\
\hline 2012 & $\begin{array}{c}14437.2 \\
(7.5)\end{array}$ & $\begin{array}{c}5824.2 \\
(3.0)\end{array}$ & $\begin{array}{c}20261.4 \\
(10.5)\end{array}$ & $\begin{array}{c}70375.6 \\
(36.4)\end{array}$ & $\begin{array}{c}24170.04 \\
(100)\end{array}$ \\
\hline 2013 & $\begin{array}{c}17613.6 \\
(7.5)\end{array}$ & $\begin{array}{c}7326.1 \\
(3.1)\end{array}$ & $\begin{array}{c}24939.7 \\
(10.5)\end{array}$ & $\begin{array}{c}82477.2 \\
(35)\end{array}$ & $\begin{array}{c}28575.25 \\
(100)\end{array}$ \\
\hline 2014 & $\begin{array}{c}21563.5 \\
(7.8) \\
\end{array}$ & $\begin{array}{c}8378.0 \\
(3.0) \\
\end{array}$ & $\begin{array}{c}29941.5 \\
(10.8) \\
\end{array}$ & $\begin{array}{c}96574.3 \\
(34.8) \\
\end{array}$ & $\begin{array}{c}33456.19 \\
(100)\end{array}$ \\
\hline 2015 & $\begin{array}{c}26507.1 \\
(8.2)\end{array}$ & $\begin{array}{c}10565.9 \\
(3.3)\end{array}$ & $\begin{array}{l}37073 \\
(11.5)\end{array}$ & $\begin{array}{c}114040.6 \\
(35.1)\end{array}$ & $\begin{array}{c}40741.68 \\
(100)\end{array}$ \\
\hline 2016 & $\begin{array}{c}36025.3 \\
(9.1) \\
\end{array}$ & $\begin{array}{c}14692.3 \\
(3.77) \\
\end{array}$ & $\begin{array}{l}50717.6 \\
(12.87) \\
\end{array}$ & $\begin{array}{c}133886.0 \\
(34)\end{array}$ & $\begin{array}{c}47908.74 \\
(100)\end{array}$ \\
\hline 2017 & $\begin{array}{c}44075.80 \\
(9.6)\end{array}$ & $\begin{array}{c}14258.53 \\
(3.1)\end{array}$ & $\begin{array}{c}58344.33 \\
(12.65) \\
\end{array}$ & $\begin{array}{c}149697.1 \\
(32.5)\end{array}$ & $\begin{array}{c}55064.95 \\
(100)\end{array}$ \\
\hline Mean & 19110.4300 & 7217.0430 & 26328.4530 & 79803.810 & 28504.9010 \\
\hline
\end{tabular}

Source: RBI, Relevant issues of Report on Trend Progress of Banking in India

Note: Figures in the parentheses are percentage to total. 
International Journal of Trend in Scientific Research and Development (IJTSRD) ISSN: 2456-6470

Table:1.1Compound growth rates and T-calculated values of commercial banks advances during 2008-17

\begin{tabular}{|l|l|l|l|l|l|}
\hline Calculated Element & $\begin{array}{l}\text { Direct } \\
\text { Agricultural } \\
\text { Advances }\end{array}$ & $\begin{array}{l}\text { Indirect } \\
\text { Agricultural } \\
\text { Advances }\end{array}$ & $\begin{array}{l}\text { Total } \\
\text { Advanced }\end{array}$ & $\begin{array}{l}\text { Priority } \\
\text { Sector } \\
\text { Advances }\end{array}$ & $\begin{array}{l}\text { Total } \\
\text { Advances }\end{array}$ \\
\hline Compound growth rate & $26.94 \%$ & $25.09 \%$ & $26.47 \%$ & $21.95 \%$ & $22.43 \%$ \\
\hline t - value & $4.6281^{*}$ & $4.8161^{*}$ & $4.6947^{*}$ & $5.8185^{*}$ & $5.7591^{* *}$ \\
\hline
\end{tabular}

Source: Computed from Table 1

Note: *Significant at both 1 per cent and 5 per cent levels

Table 1 reveals the advances to agriculture and priority sector advances. It can be seen from the table that both the percentages of advances to agriculture and priority sectors are below prescribed norms due to inclusion of foreign banks. As segregations of advances bank-wise are not available only total advances are considered. The annual compound growth rates are impressive and significant both at 1 and 5 per cent levels.

\section{BANK CATEGORY WISE SHARE OF PRIORITY SECTOR ADVANCES}

To present a clear picture of priority sector advances bank wise share is presented in Table 2 .

Table 2: Bank Category- wise Priority Sector Advances of Commercial Banks in India during 2008-17

\begin{tabular}{|c|c|c|c|}
\hline ending & \multicolumn{3}{|c|}{ Priority sector advances of commercial Bank in India } \\
\hline $31^{\text {st }}$ March & Public sector Banks & Private sector Banks & Foreign Banks \\
\hline 2008 & $\begin{array}{l}199786 \\
(41.2)\end{array}$ & $\begin{array}{r}36648 \\
(44.1)\end{array}$ & $\begin{array}{l}11835 \\
(34.0)\end{array}$ \\
\hline 2009 & $\begin{array}{c}244456 \\
(43.6)\end{array}$ & $\begin{array}{r}48920 \\
(47.3)\end{array}$ & $\begin{array}{l}17960 \\
(34.4)\end{array}$ \\
\hline 2010 & $\begin{array}{c}307046 \\
(43.6)\end{array}$ & arch $\begin{array}{l}69886 \\
(43.6)\end{array}$ & $\begin{array}{r}23843 \\
(35.3)\end{array}$ \\
\hline 2011 & $\begin{array}{c}409748 \\
(40.3)\end{array}$ & lopment 106586 & $\begin{array}{r}30439 \\
(34.4)\end{array}$ \\
\hline 2012 & $\begin{array}{r}521376 \\
(39.7) \\
\end{array}$ & $456=6 \begin{array}{c}144549 \\
(47.8)\end{array}$ & $\begin{array}{l}37831 \\
(33.4) \\
\end{array}$ \\
\hline 2013 & $\begin{array}{r}610450 \\
(44.7)\end{array}$ & $\begin{array}{l}164068 \\
(46.8)\end{array}$ & $\begin{array}{l}50254 \\
(39.5)\end{array}$ \\
\hline 2014 & $\begin{array}{c}720083 \\
(42.5) \\
\end{array}$ & $\begin{array}{l}190207 \\
(46.8) \\
\end{array}$ & $\begin{array}{l}55453 \\
(34.3)\end{array}$ \\
\hline 2015 & $\begin{array}{c}864564 \\
(41.7) \\
\end{array}$ & $\begin{array}{r}215552 \\
(46.0) \\
\end{array}$ & $\begin{array}{l}60290 \\
(35.1)\end{array}$ \\
\hline 2016 & $\begin{array}{c}1022925 \\
(41.0)\end{array}$ & $\begin{array}{c}249139 \\
(46.7) \\
\end{array}$ & $\begin{array}{l}66796 \\
(39.1)\end{array}$ \\
\hline 2017 & $\begin{array}{c}1129993 \\
(37.4)\end{array}$ & $\begin{array}{c}280419 \\
(39.4)\end{array}$ & $\begin{array}{l}80559 \\
(40.9)\end{array}$ \\
\hline Mean & $\begin{array}{c}603042.70 \\
(41.57)\end{array}$ & $\begin{array}{c}150597.40 \\
(45.13)\end{array}$ & $\begin{array}{l}43526 \\
(36.04)\end{array}$ \\
\hline
\end{tabular}

(Rs. Crores)

Sources: 1. RBI, Relevant issues of Report on Trend and progress of banking in India

2. RBI, Relevant issues of Report on Currency and Finance

Note: Figures in brackets are percentage to Net Bank credit (NBC) up to 2017; there offer they are percentages to Adjusted Net Bank credit (NABC) or credit equivalent to off balance sheet exposure which is higher in the respective groups. 
International Journal of Trend in Scientific Research and Development (IJTSRD) ISSN: 2456-6470

Table; 2.1 Compound growth rates and T-calculated values of Scheduled of by bank category wise during 2008-17

\begin{tabular}{|c|c|c|c|}
\hline Calculated Element & Public Sector Banks & $\begin{array}{c}\text { Private Sector } \\
\text { Banks }\end{array}$ & Foreign Banks \\
\hline Compound growth rate (\%) & 21.23 & 25.37 & 23.75 \\
\hline t-value & $4.8946^{*}$ & $5.6323^{*}$ & $6.0681^{*}$ \\
\hline
\end{tabular}

Source: Computed from table 2

Note : *Significant at both1 per cent and 5 per cent levels

It is clear from table 2 that public sector banks in India achieved the prescribed norm (40 per cent) by RBI all the years except in 2012 and in 2017. The share of priority sector advances fell short of only 0.3 in 2012 and 2.6 per cent in 2017. Private sector banks also achieved the targets (40 per cent) of lending except in 2017, the share of priority sector advances fell short of only 0.6 percent. Foreign banks have exceeded their target of 32 per cent prescribed by RBI in all the years. The Compound annual growth rates are impressive and significant both at 1 and 5 per cent levels.

\section{DIFFERENTIAL INTEREST RATE SCHEME (DRI)}

This is one of the constituents of priority sector comes under tertiary sector. The Differential Rate of Interest Scheme (DRI Scheme) was introduced during 1972, following the ecommendations of the committee under the Chairman of DR.R.K. Hazari ${ }^{2}$. The scheme was meant to ensure and provide access to institutional credit for certain sections of the poor. The eligible persons obtain loans at a uniform concessional interest rate of 4 per cent. At present 1 per cent of the total advances of commercial banks should earmark under DRI scheme. A Formal obligation was also laid on the private sector banks in December, 1978 to implement the scheme and to achieve the target of lending at least one per cent of their aggregate advances outstanding at the end. The progress achieved under DRI scheme is presented in Table 3

Table 3: Commercial Banks' Lending under DRI scheme during 2008-17 (Number of accounts in million and amount in billion)

\begin{tabular}{|c|c|c|c|c|}
\hline Year & $\begin{array}{c}\text { Number of } \\
\text { accounts }\end{array}$ & $\begin{array}{c}\text { Amount } \\
\text { outstanding for } \\
\text { DRI }\end{array}$ & Advances & $\begin{array}{c}\text { DR percentage } \\
\text { to total } \\
\text { advances }\end{array}$ \\
\hline 2008 & 0.37 & 3.85 & 8908.66 & 0.04 \\
\hline 2009 & 0.33 & 3.37 & 11578.07 & 0.03 \\
\hline 2010 & 0.39 & 4.90 & 15174.97 & 0.03 \\
\hline 2011 & 0.26 & 6.34 & 19470.99 & 0.03 \\
\hline 2012 & 0.26 & 6.69 & 24170.04 & 0.03 \\
\hline 2013 & 0.31 & 7.53 & 28575.25 & 0.03 \\
\hline 2014 & 0.37 & 7.52 & 33456.19 & 0.02 \\
\hline 2015 & 0.42 & 7.15 & 40741.68 & 0.02 \\
\hline 2016 & 0.43 & 8.02 & 47908.74 & 0.02 \\
\hline 2017 & NA & NA & 55064.95 & - \\
\hline Mean & 0.3489 & 6.1522 & 28504.9540 & 0.02 \\
\hline
\end{tabular}

Source: RBI: Relevant issues of Statistical Tables relating to Banking $\mathrm{NA}=$ Not available 
International Journal of Trend in Scientific Research and Development (IJTSRD) ISSN: 2456-6470

Table; 3.1 Compound growth rates and t-calculated values of commercial banks advances under DRI Scheme during 2008-17

\begin{tabular}{|c|c|c|c|}
\hline Calculated Element & Number of Accounts & Amount out standing & Advances \\
\hline Compound growth rate ( \%) & 1.90 & 9.61 & 22.43 \\
\hline t- value & $16.5781^{*}$ & $10.8412^{*}$ & 5.7591 \\
\hline
\end{tabular}

Source: Computed from table 3

Note: *Significant at both1 per cent and 5 per cent levels

It is evident from Table 3, the number of borrowed accounts under DRI scheme increased from 0.37 million in 2008 to 0.43 million in 2017. The amount outstanding against these accounts also increased from Rs.3.85 billion in 2008 to Rs.8.02 billion in 2017 though there is a setback in the amount outstanding. Despite this increase, however, the share of the DRI advances to total advances was below stipulated norm (1 per cent) by RBI for the study years. The compound annual growth rates are significant at both 1 and 5 per cent levels. This is quite understandable that there is no obligation for foreign exchange banks and the other reason is the mounting over dues.

\section{ADVANCES TO WEAKER SECTIONS}

This is also one of the constituents of priority sector comes under tertiary sector.

As per the RBI norm, commercial banks advances to weaker sections should be 10 per cent of total advances ${ }^{3}$.

Commercial banks advances to weaker section was presented in Table 4

Table 4: Commercial Banks' Advances to Weaker Sections during 2008-17(Number of accounts in million and amount in billion)

\begin{tabular}{|c|c|c|c|c|}
\hline Year & Number of accounts & $\begin{array}{c}\text { Amount outstanding } \\
\text { for weaker sections }\end{array}$ & $\begin{array}{c}\text { Percentage of } \\
\text { weaker } \\
\text { sections } \\
\text { advances } \\
\text { to total }\end{array}$ \\
\hline 2008 & 29.20 & 271.9 & 8908.66 & 3.05 \\
\hline 2009 & 38.34 & 291.8 & 11578.07 & 2.52 \\
\hline 2010 & 21.19 & 398.2 & 15174.97 & 2.62 \\
\hline 2011 & 39.67 & 129.9 & 19470.99 & 2.62 \\
\hline 2012 & 22.33 & 1269.35 & 24170.04 & 5.25 \\
\hline 2013 & 24.10 & 1670.41 & 28575.25 & 5.85 \\
\hline 2014 & 26.13 & 2095.62 & 33456.19 & 6.26 \\
\hline 2015 & 28.79 & 2463.15 & 40741.68 & 6.05 \\
\hline 2016 & 32.97 & 2939.60 & 47908.74 & 6.13 \\
\hline 2017 & NA & NA & 55064.95 & NA \\
\hline Mean & 29.1911 & 1281.1033 & 28504.9540 & 5.01 \\
\hline
\end{tabular}

Source:RBI: Relevant issues of Statistical Tables relating to Banking

Note: $\mathrm{NA}=$ not available 
International Journal of Trend in Scientific Research and Development (IJTSRD) ISSN: 2456-6470

Table:4.1 Compound growth rates and t-calculated values of commercial banks advances under DRI Scheme during 2008-17

\begin{tabular}{|c|c|c|c|}
\hline Calculated Element & Number of Accounts & $\begin{array}{c}\text { Amount } \\
\text { outstanding for } \\
\text { weaker sections }\end{array}$ & Advances \\
\hline Compound growth rate( \%) & 1.53 & 34.66 & 22.43 \\
\hline $\mathrm{t}$-value & $13.1586^{*}$ & $3.6105^{*}$ & $5.7591^{*}$ \\
\hline
\end{tabular}

Source: Computed from table 4

Note: *Significant at both1 per cent and 5 per cent levels

It is evident from table 4 that the number of borrowed accounts under weaker section advances increased from 29.20 million in 2008 to 32.97 million in 2017. The amount outstanding against these accounts also increased from Rs.271.9 billion in 2008 to Rs.2939.60 billion in 2017.

Although both number of accounts and amount outstanding on them increased, the commercial banks failed to meet the norm (10 per cent of total advances) set up by RBI. This is due several reasons like i) mounting of overdues and non-performingassets (NPA) ii) foreign banks have no obligation iii) weaker section finance is not profitable avenue for commercial banks. The compound annual growth rate is significant at 1 per cent level.

\section{COMMERCIAL BANKS CREDIT TO SMALL SCALE INDUSTRIES}

Small scale industries constitute secondary sector of priority sector. These units satisfy the criteria for investment in plant and machinery and equipment as per Micro Small and Medium Enterprises development act 2006(MSMED). Investment in plant and machinery should not exceed twenty-five lakhs rupees for Micro enterprises for Small enterprises it should be more than twenty-five lakhs rupees but should not exceed five crore rupees. For the investment the criteria are; it should not exceed ten lakh rupees for Micro enterprises for Small enterprises more than ten lakh rupees but should not exceed two crore rupees ${ }^{4}$. Commercial banks advances to Small scale industries were shown in Table 5.

Table 5: Commercial Banks’ Advances to Small Scale Industries during 2008-17

\begin{tabular}{|c|c|c|c|}
\hline Year & $\begin{array}{c}\text { A mount outstanding for } \\
\text { Small scale industries }\end{array}$ & Total advances & $\begin{array}{c}\text { Percentage of small scale } \\
\text { industries advances to } \\
\text { total advances }\end{array}$ \\
\hline 2008 & 712.09 & 8908.66 & 8.0 \\
\hline 2009 & 834.99 & 11578.07 & 7.2 \\
\hline 2010 & 1012.85 & 15174.97 & 6.68 \\
\hline 2011 & 1273.22 & 19470.99 & 6.53 \\
\hline 2012 & 2643.2 & 24170.04 & 10.93 \\
\hline 2013 & NA & 28575.25 & - \\
\hline 2014 & 3622.91 & 33456.19 & 10.83 \\
\hline 2015 & 4785.27 & 40741.68 & 11.75 \\
\hline 2016 & 5275.85 & 47908.74 & 11.01 \\
\hline 2017 & 7297.00 & 55064.95 & 13.25 \\
\hline Mean & 3050.8200 & 28504.9540 & 10.70 \\
\hline
\end{tabular}

Sources: 1. RBI, Relevant issues of Statistical Tables relating to Banking

2. RBI, Relevant issues of Report Trend and Progress of Banking in India

Note: *Significant at 1 level, NA= not available 
International Journal of Trend in Scientific Research and Development (IJTSRD) ISSN: 2456-6470

Table:5.1 Compound growth rates and t-calculated values of commercial banks advances under DRI Scheme during 2008-17

\begin{tabular}{|c|c|c|}
\hline Calculated Element & $\begin{array}{c}\text { Amount outstanding for small } \\
\text { scale industries }\end{array}$ & Total Advances \\
\hline Compound growth rate (\%) & 33.76 & 22.43 \\
\hline $\mathrm{t}$ - value & $3.8949^{*}$ & $5.7591^{*}$ \\
\hline
\end{tabular}

Source: Computed from table 4

Note: * Significant at both1 per cent and 5 per cent levels

Table 5 reveals that the amount outstanding of small scale industries advances increased from Rs.712.09 billion in 2008 to Rs.7297. billion in 2017. The increase rate is 10.24 times. The percentage of outstanding advances for small enterprises was increased from 8 per cent in 2008 to 13.25 per cent in 2017.The compound annual growth rates are impressive and significant at both 1 and 5 per cent levels.

\section{RECOVERY PERFORMANCE OF COMMERCIAL BANKS}

The problem of overdues has been quite challenging task to credit institutions in the country. Poor recovery of overdues cripples the capacity of credit institutions to draw refinance from NABARD. Recycling of funds becomes an impossible task, when the overdues reach the danger level. The banking sector is expected to achieve some of the socio-economic objectives of planned development. However, they perform the role when banks are financially sound. Because of the phenomenon of mounting overdues, banks are very much affected. There will be always some bad and doubtful debts. But with greater attention to priority sector the problem of overdues has assumed greater proportions stated. ${ }^{\mathbf{5}}$ the recovery performance of commercial banks was shown in Table 6.

Table 6: Recovery Position of Commercial Banks during 2009-17 (Rs. Crores)

\begin{tabular}{|c|c|c|c|}
\hline Year & Demand & Recovery & $\begin{array}{c}\text { Percentage of Recovery } \\
\text { to Demand }\end{array}$ \\
\hline 2009 & 33544 & 25002 & 74.5 \\
\hline 2010 & 45454 & 45733 & 84 \\
\hline 2011 & 46567 & 37298 & 80 \\
\hline 2012 & 73802 & 58840 & 79.7 \\
\hline 2013 & 95100 & 71739 & 75.4 \\
\hline 2014 & 119084 & 90660 & 76.1 \\
\hline 2015 & 124400 & 92000 & 74.09 \\
\hline 2016 & 182200 & 138300 & 75.9 \\
\hline 2017 & 191800 & 142900 & 74.51 \\
\hline Mean & 101327.89 & 78052.44 & 77.03 \\
\hline
\end{tabular}

Sources: 1 . RBI, Relevant issues of Report on Currency and Finance

2. RBI, Relevant issues of Report Trend and Progress of Banking in India

Table: 6.1 Compound growth rates and t-calculated values of commercial banks advances under DRI Scheme during 2008-17

\begin{tabular}{|c|c|c|}
\hline Calculated Element & Demand & Recovery \\
\hline Compound growth rate( \%) & 24.35 & 24.35 \\
\hline $\mathrm{t}-$ value & $* 5.2243$ & $* 5.5741$ \\
\hline
\end{tabular}

Source: Computed from table 4

Note: *Significant at both1 per cent and 5 per cent levels

Table 6 reveals the recovery position of commercial banks. The recovery rate is 74.5 per cent in 2008 . It is 84 per cent in 2005 which best performance in terms of recovery when compared with that of other years. But in 2010 the recovery rate decrease to 80.1 per cent. In 2011 it is 79.7 per cent again it is decreased to 75.4 per cent in 2016. There is minor improvement of recovery in 2013 with the per cent of 76.1 where as it is decreased to 74.09 per cent in 2017 It is slightly 
improved in 2015 with the percentage of 75.9 percent and it is decreased to 74.51 per cent in 2017.

\section{CONCLUSION:}

The percentage of agricultural advances by commercial banks below stipulated norm due to inclusion of foreign banks. Public sector banks failed to achieve the norm during 2012 and 2017 but for the rest years their achievement is good while private sector banks achieved the target except in 2017 whereas foreign banks reached the norm for all the years. The percentage of Commercial banks' lending under DRI scheme is below the stipulated norm for all the years. The share of weaker section advances by commercial banks is also below the norm. It is due to mounting of over dues and Non-Performing
Assets(NPAs).Commercial banks' advances to small scale industries are satisfactory. The overall average recovery rate of commercial banks is 77.03 per cent.

REFERENCES:

1. RBI: "Report on Currency and Finance, Mumbai, 2017.

2. Vimala, P. "A Study on Priority Sector lending in Kerala", MGU, Kerala, 2002

3. RBI, Master Circular-Priority Sector LendingTargets and Classification, www.rbi.org.in , July 01,2003,pp.11-12.

4. Op.cit. RBI 08.

5. Satyam Sundaram, I. "Rural Development", Himalaya Publishing House, Bombay, 1997, pp.455.

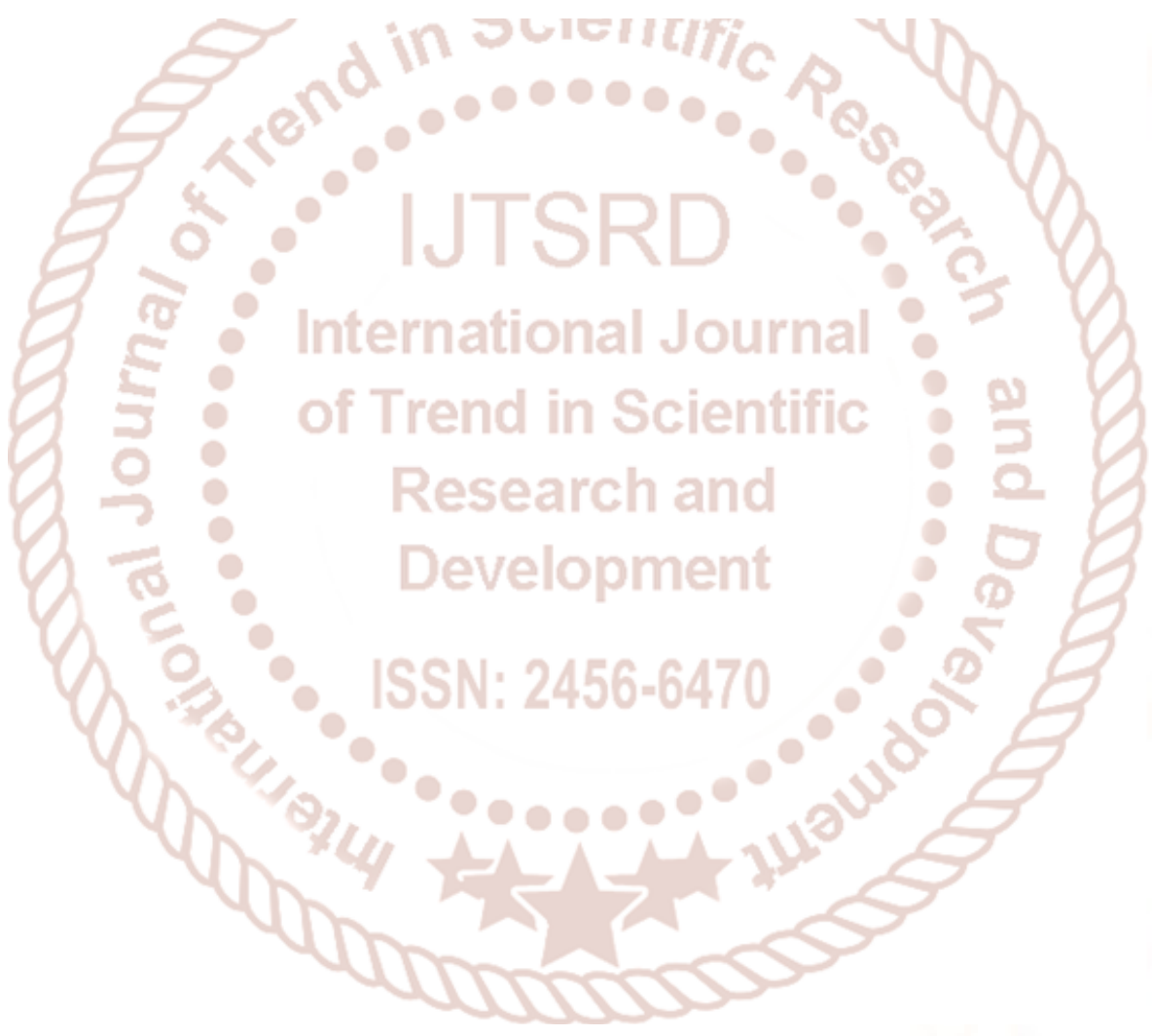

